\title{
Characteristics of the active Luoshan Fault since Late Pleistocene, North Central China
}

\author{
Min Wei $\left({ }^{1}\right)$, Jiao Decheng $\left({ }^{2}\right)$, Chai Chizhang $\left({ }^{2}\right)$, Zhang Peizhen $\left({ }^{1}\right)$ and Mao Fengying $\left({ }^{1}\right)$ \\ ${ }^{1}$ ) Institute of Geology, China Seismological Bureau, Beijing, China \\ $\left.{ }^{2}\right)$ Seismological Bureau of Ningxia Province, Yinchuan, China
}

\begin{abstract}
The Luoshan Fault located at the northeastern margin of Tibet plateau strikes roughly N-S, and is composed of six left-stepping sections with a total length of $60 \mathrm{~km}$. Much evidence suggests that the Luoshan Fault is a reverse right-lateral strike-slip fault. The largest right-lateral strike-slip displacement and the most abundant dextral offset phenomena are located along the central section. Based on the right-lateral strike-slip offsets of the oldest alluvial fan, and of a gully and on the average displacement of the same order of gullies, the minimum slip-rate has been $2.15 \pm 0.2 \mathrm{~mm} / \mathrm{yr}$ since Late Pleistocene. Many surface rupture phenomena, such as fault scarps with fresh free-face, ground fissures, displacements of very young gullies, imply that a recent earthquake occurred along this fault. Combining the historical catalogue and our results, we believe that the 1561 A.D. earthquake was produced by the Luoshan Fault. Three paleoearthquakes were determined by means of paleoseismic studies along the Luoshan Fault: they occurred after $8200 \pm 600$ years BP, between $3130 \pm 240$ years BP and $4150 \pm$ \pm 120 years C.BP, and before $2230 \pm 170$ years BP, respectively.
\end{abstract}

Key words northeastern margin of Tibet plateau - paleoseismology - slip-rate

\section{Introduction}

The Tibetan plateau is a fast deforming zone characterized also by important seismicity. The northeastern margin of the Tibetan plateau is characterized by several main systems of active faults from southwest to northeast. They are (fig. 1c): the Haiyuan Fault (HYF), the Zhongwei-Tongxin Fault (ZTF), the Yantongshan Fault (YTF), Niushoushan (NSF)-Luoshan (LSF)Yunwushan Fault (YWF), Huanghe Fault (HHF), the Helanshan Fault (HLF), Zhengyiguan Fault (ZGF) and the Sanguankou Fault (SGF). The Niushoushan (NSF)-Luoshan (LSF)Yunwushan Fault (YWF) zone separates the

Mailing address: Dr. Min Wei, Institute of Geology, China Seismological Bureau, Beijing 100029, China; e-mail: minww@263.net.cn
Yinchuan graben and the Ordos block. Since 1980s, many advances in earthquake geology have been made and many important results have been obtained in the region (Qidong et al., 1984; Deng et al., 1986; Zhang et al., 1988, 1990, 1991; Deng and Zhang,1990; Burchfiel et al., 1991). Strong earthquakes frequently occur in this area. According to the Institute of Geology, Seismological Bureau of China (Deng and Zhang, 1990), the $240 \mathrm{~km}$ long Haiyuan Fault (HYF) was responsible for the $1920 \boldsymbol{M} \approx 8.5$ earthquake (Gu $e t$ al., 1989), being characterized by a $6-10 \mathrm{~mm} / \mathrm{yr}$ left-lateral strike slip rate during the Holocene. Wang et al. (1990) concluded that the $200 \mathrm{~km}$ long Zhongwei-Tongxin Fault (ZTF) was responsible for $\boldsymbol{M} \approx 7.5$ of the 1709 earthquake (Gu et al., 1989), being characterized by a $3.58 \mathrm{~mm} / \mathrm{yr}$ leftlateral strike slip rate during the Holocene. Evidence for Holocene activity has hardly been found along the Yantongshan (YTF) and Niushoushan faults (NSF). The NNE trending Helanshan Fault (HLF) along the western margin of Yinchuan graben is a normal and right-lateral strike-slip fault. It cuts Late Pleistocene to Holo- 
cene alluvial fans, forming a SE facing scarp, and offsets right laterally for $1.45 \mathrm{~m}$ and vertically for $0.95 \mathrm{~m}$ the Great Wall of the Ming Dynasty (about 400 years BP). The offset of the Great Wall is probably a result of the $\boldsymbol{M} \approx 8$ earthquake of 1739 (Zhang et al., 1986) and four Holocene seismic events have been identified by Deng (1996) on the basis of paleoseismological trenching. The Huanghe Fault (HHF) forms the eastern boundary of Yinchuan graben. Liao et al. (2000) and Chai et al. (2001) studied its southern part and estimated a normal slip rate is $0.23-0.25 \mathrm{~mm} / \mathrm{yr}$ and $\mathrm{rec}-$ ognized two Holocene earthquakes that ruptured the fault. According to the Research Group on «Active Fault System around Ordos Massif» (1988), the Luoshan Fault (LSF) is a left-lateral strike slip fault. Moreover, in 1561, another strong earthquake $\boldsymbol{M} \approx 7.3$ (Gu et al., 1989) struck an area close to the Luoshan Mountain. In order to cast light on the seismotectonics of the northeastern margin of the Tibetan plateau, we performed detailed mapping along the Luoshan Fault, finding geological and geomorphic evidence that this fault is a right-lateral strike-slip fault which could be related to strong earthquakes, and particularly to the 1561 A.D. $\boldsymbol{M} \approx 7.3$ earthquake. At two investigated sites, the slip rate of the fault was calculated, while three Holocene paleoearthquakes have been recognized through paleoseismological analyses.

\section{Seismotectonic framework of the Tibet region}

At least $1500 \mathrm{~km}$ of north-south crustal shortening have occurred because of the collision of India and Eurasia which led to eventual construc- tion of the Cenozoic Tibetan plateau since the Late Cretaceous (Molnar and Tapponnier, 1975). Under steady NE directional compressional stress from India plate, three main types of structures were formed in the plateau (fig. 1b): thrust fault belts associated with indenting basins; strike-slip fault belts associated with the lateral extrusion and rotation of blocks; normal fault belts associated with extensional graben-type basins.

The compressive convergent structures are located around the Tibet plateau. The Himalaya compressive convergent structure zones are located on the southern margin of the plateau, involving different structures with a convergence rate of 20 $\pm 10 \mathrm{~mm} / \mathrm{yr}$ (Avouac and Tapponier, 1993). Western Kunlun thrust belt is located to the northwest of the plateau and defines the western termination of the Altyn Tagh Fault System. The Qilianshan thrust belt is located on the northeast boundary of the plateau, the rate of horizontal convergence on some main faults is estimated as 4-5 $\mathrm{mm} / \mathrm{yr}$, while that for the entire convergence zone is up to $15 \mathrm{~mm} / \mathrm{yr}$ (Avouac and Tapponier, 1993). The Liupanshan thrust belt is located on the northeast margin of the plateau and consists of Cenozoic fold and thrust faults, and the amount of convergence since Quaternary has been deduced to be 11.4-15.4 km (Zhang et al., 1991). Longmenshan thrust belt is located on the middle segment of the eastern margin of the plateau. Avouac and Tapponier (1993) deduced a horizontal shorting rate of about $10 \mathrm{~mm} / \mathrm{yr}$ for this zone.

The rather rigid Tarim massif might be a large obstacle to the northward transfer of deformation. The main part of Tibet was compressed and contracted, while the blocks within Tibet were moved laterally along some major boundary faults. The

Fig. 1a-c. a) Sketch map of China active faults. Insert A shows the area of fig. 1b. b) Active tectonic map of the Tibet plateau. Earthquakes which only occurred in China are labeled on the map (from Gu et al., 1989 and China Seismostation Report compiled by the Institute of Geophysics, CSB, unpublished). Inset B shows the location of the study area. c) Active faults map of the eastern margin of the Tibet plateau. Inset B in fig. 1b shows the location of the study area. Faults: ZGF - Zhengyiguan Fault; HLF - Helanshan Fault; SGF - Sanguankou Fault; HHF - Huanghe Fault; NSF - Niushoushan Fault; ZTF - Zhongwei-Tongxin Fault; YTF - Yantongshan Fault; LSF - Luoshan Fault; HYF - Haiyuan Fault; YWF - Yunwushan Fault; LPF - Liupanshan Fault. Mountains: HLM - Helanshan Mountain; NSM - Niushanshan Mountain; XTM - Xiangshan and Tianjinshan mountain; LSM - Luoshan Mountain; YWM - Yunwushan Mountain; LPM - Liupanshan Mountain. Magnitude and timing of five $M \geq 7$ historical earthquakes are labeled on the map (Gu et al., 1989). 


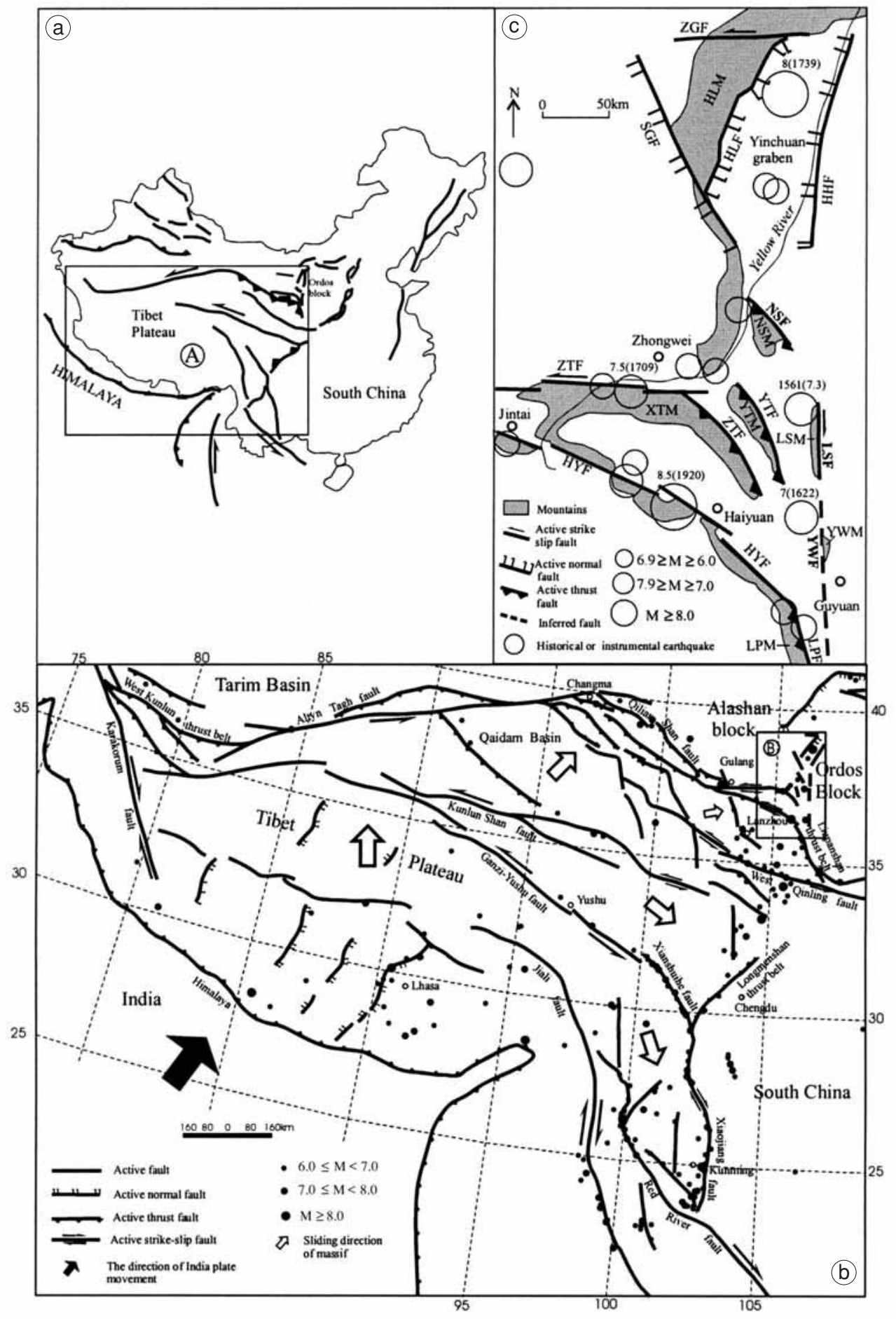


Altyn Tagh Fault is one of the largest intraplate strike slip faults with a strike of NEE and a total length of $1600 \mathrm{~km}$, constituting the boundary between the Tibet plateau and Tarim massif (fig. 1b). There is still noticeable disagreement in the estimates of the left-lateral slip rate along the fault, ranging from $6.4 \mathrm{~mm} / \mathrm{yr}$ (Research Group on Altyn Active Fault, 1992) to $30 \mathrm{~mm} / \mathrm{yr}$ (Avouac and Tapponnier, 1993). The KarakorumJiali Fault Zone is considered to be the southern limit of the eastward extrusion of the plateau, and displays right-lateral strike-slip, in contrast to the Altyn Tagh Fault. A right lateral strike slip rate of 20-30 mm/yr has been estimated for this fault zone (Avouac and Tapponnier, 1993). The Kunlun shan fault, Ganzi-Yushu-Xianshuihe and Red River fault are also very famous strike-slip faults within Tibet. The 1997 Manyi $\boldsymbol{M}=7.9$ and the 2001 Kunlunshan $\boldsymbol{M}=8.1$ earthquakes occurred along the Kunlun shan fault. The surface rupture length of 2001 Kunlunshan earthquake is between 350 and $426 \mathrm{~km}$ (Xu et al., 2002).

SN-trending extensional graben systems have been recognized in Central and Southern Tibet (Tapponnier and Molnar, 1977; Molnar and Tapponnier, 1978). The strike of the graben system varies from northsouth to northeast and then to northwest. The NE-trending boundary faults of the extensional graben show left-lateral strike slip component whereas the NW-trending boundary faults have a right-lateral strike slip component.

The Luoshan Fault locates the easternmost segment of the Qilianshan-Haiyuan Fault Zone, many historical strong earthquakes occurred in this area.

\section{Geologic setting and geometry of the Luoshan Fault}

The Niushoushan-Luoshan-Yunwushan faults are in the northeasternmost margin of the Tibet plateau (fig. 1c). In this region, the structures are dominated by normal faulting bounding the east and west sides of Yinchuan graben to the north, whereas structures are dominated by strike slip and thrust faulting to the south. The Luoshan Fault belongs to this southern domain. Many strong earthquakes have been recorded in this region (fig. 1c), five $\boldsymbol{M} \geq 7$ earthquakes occurred in the past hundreds of years. They are: 1561 north of Luoshan, $\boldsymbol{M} \approx 7.3$ earthquake; 1622 north of Guyuan, $\boldsymbol{M} \approx 7.0$ earthquake; 1709 Zhongwei, $\boldsymbol{M} \approx 7.5$ earthquake; 1739 Yinchuan, $\boldsymbol{M} \approx 8.0$ earthquake, and 1920 Haiyuan, $\boldsymbol{M} \approx 8.5$ earthquake (Gu et al., 1989).

The Luoshan mountain range, with a $2624 \mathrm{~m}$ peak altitude, trends nearly SN and is composed of Ordovician rocks. The $60 \mathrm{~km}$ long Luoshan Fault is located along the eastern piedmont of the Luoshan mountain (fig. 2), it strikes $340^{\circ}-360^{\circ}$ and is composed of six sections. The displacements of gullies and streams imply that Luoshan Fault is characterized by right-lateral strike-slip, and the largest observed horizontal offset is located in the middle part of the fault $\left(\mathrm{SF}_{4}\right)$. The fault sections show reverse components of oblique right-lateral strike-slip along the northern part of the fault $\left(\mathrm{SF}_{1}\right.$ and $\left.\mathrm{SF}_{2}\right)$ and normal components of slip along the southern part of the fault $\left(\mathrm{SF}_{5}\right.$ and $\left.\mathrm{SF}_{6}\right)$. Therefore, they display pivotal movement.

The northernmost section $\mathrm{SF}_{1}$ (fig. 2): strikes $350^{\circ}$, dips westwards and is $14 \mathrm{~km}$ long. The average altitude of Luoshan Mountain is in general over $2200 \mathrm{~m}$, while it suddenly descends to $1700 \mathrm{~m}$ north of Tanzhuang along $\mathrm{SF}_{1}$. The fault is located between the mountain and alluvial fans. Fault scarps with heights of 2-4 m can be seen on the Quaternary alluvial deposits, and some fault scarps show fresh freeface. The fault is characterized by thrusting along this section, and a fault section can be seen in Tangzhuang where Ordovician rocks thrusted on Quaternary deposits (fig. 3). North of Xiquan, the fault disappeared in the Cenozoic Basin.

The segment $\mathrm{SF}_{2}$ (fig. 2): strikes $310^{\circ}-330^{\circ}$, dips SW and is only $5 \mathrm{~km}$ long. The trend of this segment is not consistent with the trend of the others, and this segment is characterized by important thrusting. South of Miaogou, Ordovician rocks thrusted onto Quaternary loess and alluvial deposits, and the fault broke the surface (fig. 4). 1-2 $\mathrm{m}$ high fault scarp is observed along this section.

The section $\mathrm{SF}_{3}$ (fig. 2): strikes $345^{\circ}-350^{\circ}$, dips east and is only $9 \mathrm{~km}$ long. Starting from this segment, the active fault gradually locates on the eastern alluvial fan of the Luoshan mountain, not 


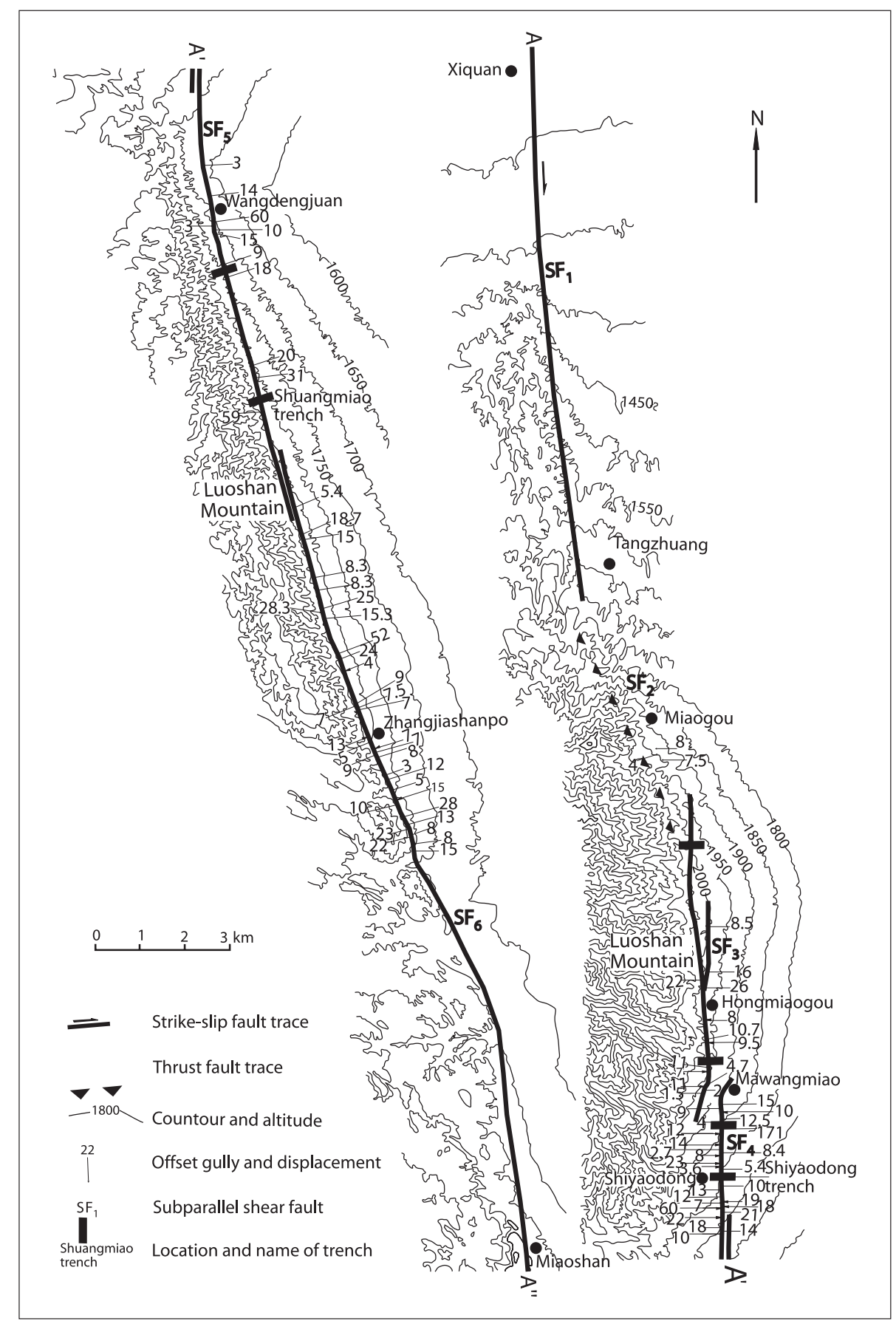

Fig. 2. Detailed map of the Luoshan Fault. 


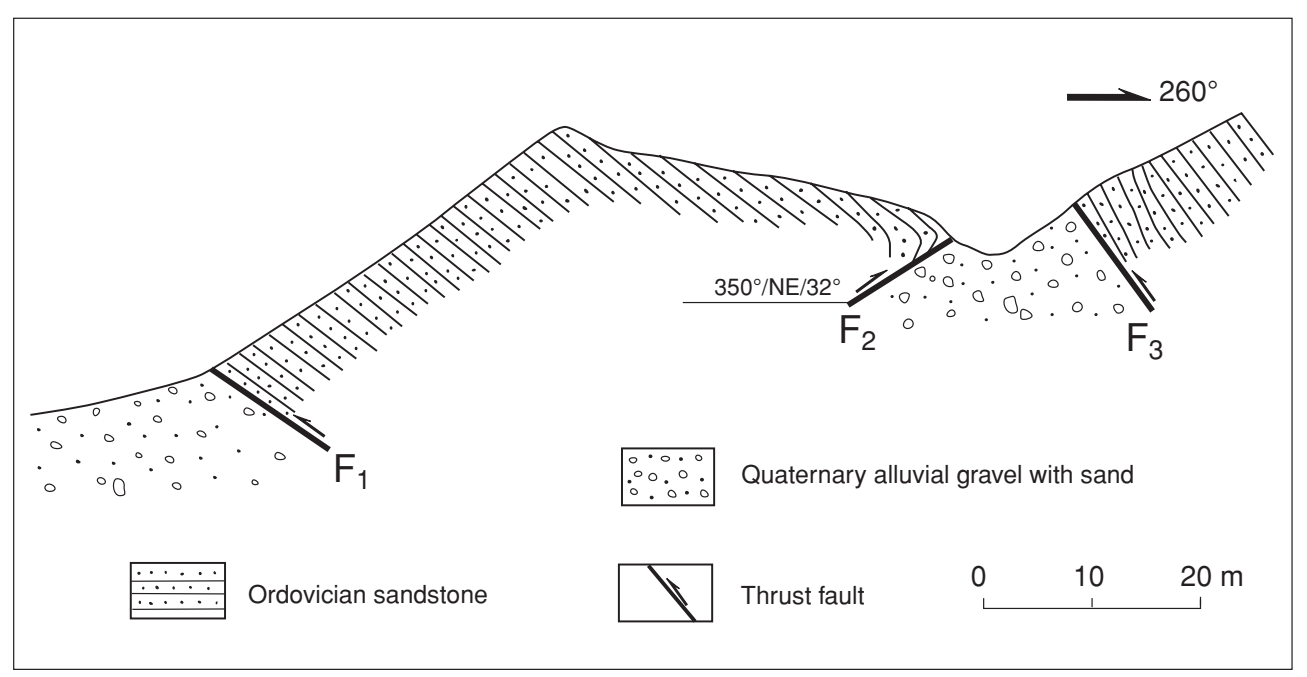

Fig. 3. Sketch of fault section in Tanzhuang.

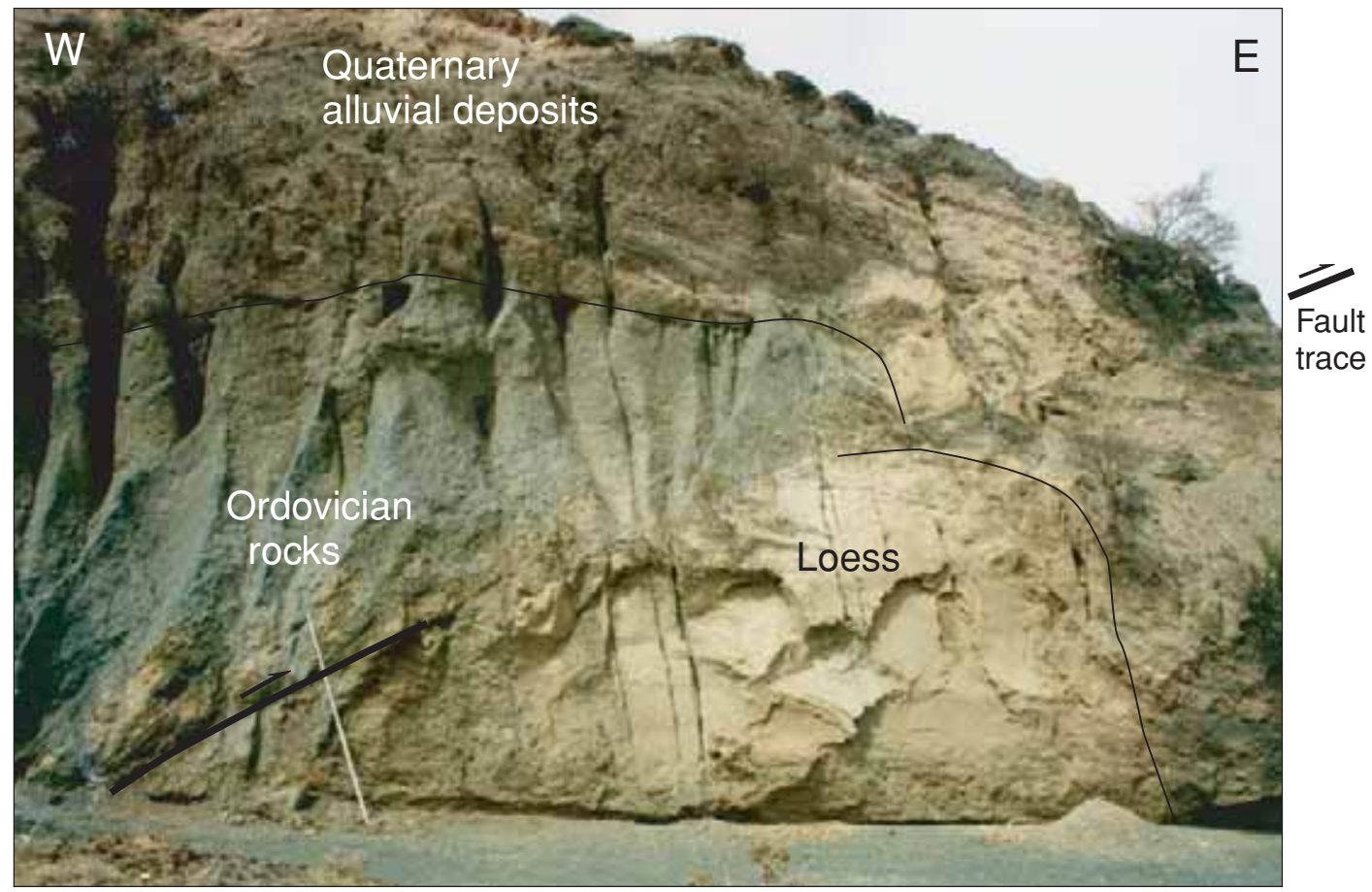

Fig. 4. Reverse splay of the fault south of Miaogou. The Ordovician rocks overlaid by alluvial gravels thrusted onto loess and the reverse fault broke the surface. View to the northeast. 
along the foot of the mountain. The horizontal displacements affect the Quaternary alluvial fans. Northward from Hongmiaogou, three gullies craved on the alluvial fan were dextrally offset by 26-22 and 16 m, respectively. Many other gullies and streams were also dextrally offset. In Hongmiaogou, the fault cut a $9 \mathrm{~m}$ high river terrace, which is displaced by a $5.2 \mathrm{~m}$ high fault scarp. West of Mawangmiao, a trench across a fault scarp on a $2 \mathrm{~m}$ high terrace was excavated. Figure

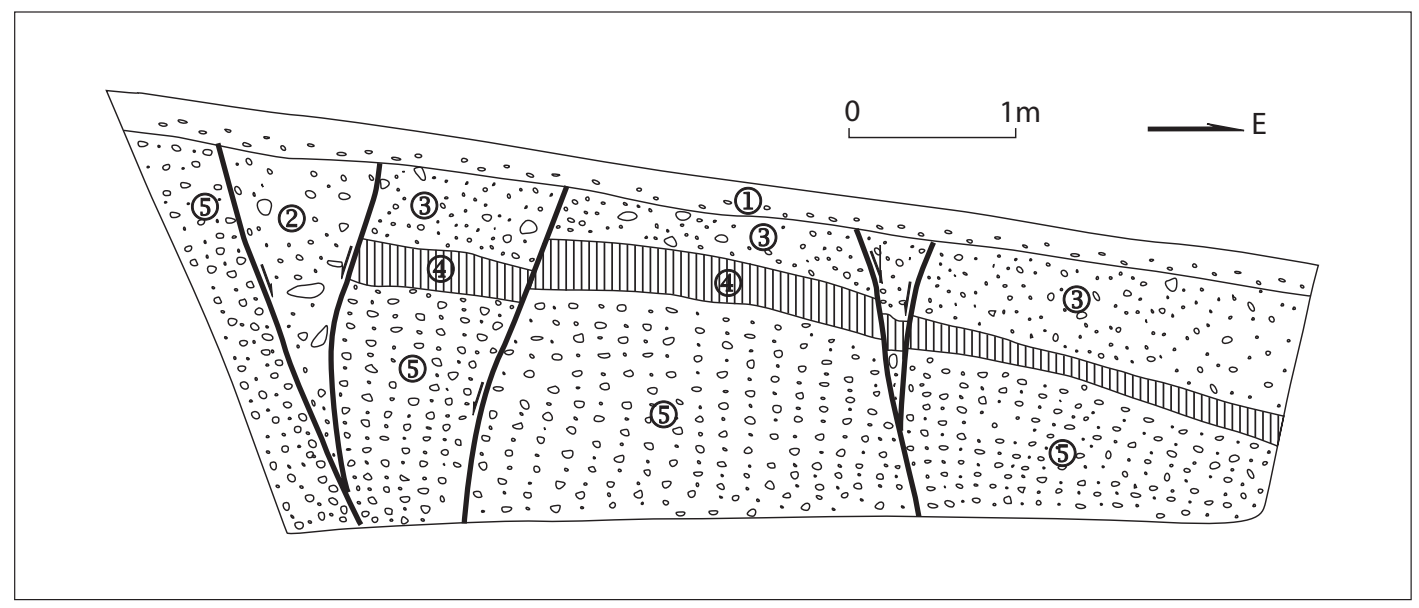

Fig. 5. Schematic log of Machanggou trench. 1 - Redeposited loess with gravel, gravel increases in the lower portion. 2 - Filled wedge that consisting of redeposited and gravel. 3 - Mixed gravel and sand. 4 - Sandy soil. 5 - Gravel bed of the alluvial terrace, consisting of gravel and sand. The thick lines indicate faults.

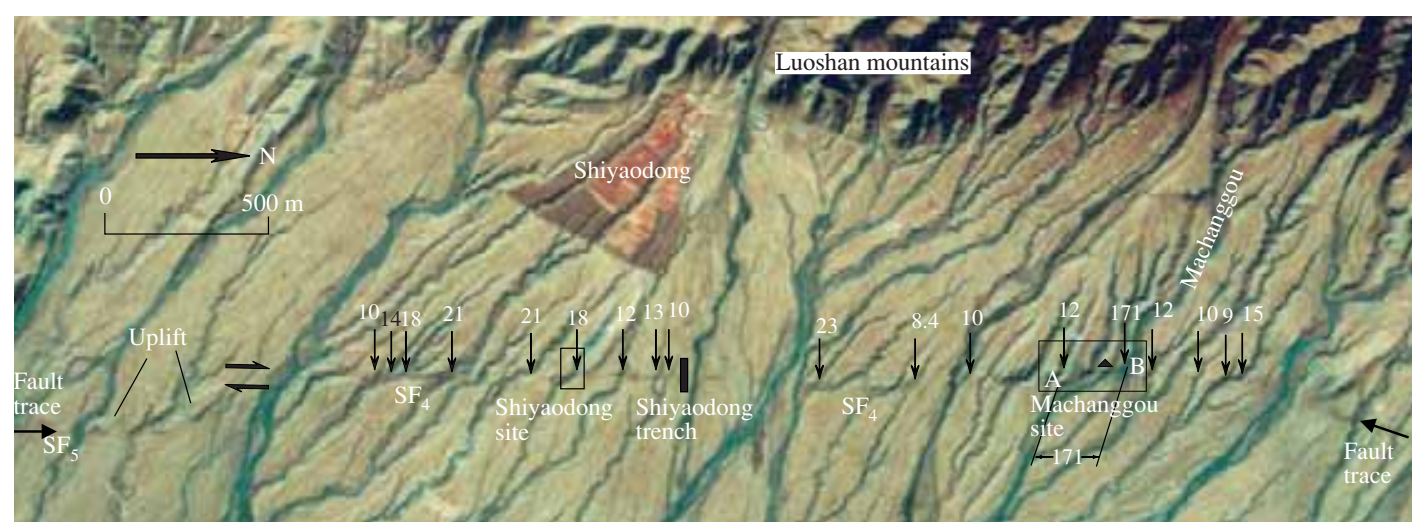

Fig. 6. Aerial view of the fault section $\mathrm{SF}_{4}$ cutting all the alluvial fans on the eastern piedmont of the Luoshan mountain and forming a remarkable fault scarp. The fault right laterally offsets most gullies. Thin arrows show offset gullies (displacement in meters); thick arrows show fault traces; the filled box indicates the trench area. The strike-slip rate is studied through two sites along this segment and empty boxes indicate the locations of the two sites, the triangle indicates sample location. A pressure ridge was formed in the overlapping area between $\mathrm{SF}_{4}$ and $\mathrm{SF}_{5}$. 
5 shows the log of north wall of the trench exposing Quaternary deposits displaced by several fault splays burried by a thin layer of fine sand with pebbles.

The Shiyaodong section $\mathrm{SF}_{4}$ (strikes NS, dips east and is only $4 \mathrm{~km}$ long) is a continuous straight fault scarp affecting the alluvial fan developed at the foothill of the Luoshan Mountain (fig. 6). Most gullies or streams show a right slip when they cross the fault. This observance and a gully offset by $18 \mathrm{~m}$ (fig. 7a) and a fault plane exposed along it showing nearly horizontal fault striae (fig. 7b), imply a right-lateral strike-slip movement along the Luoshan Fault.
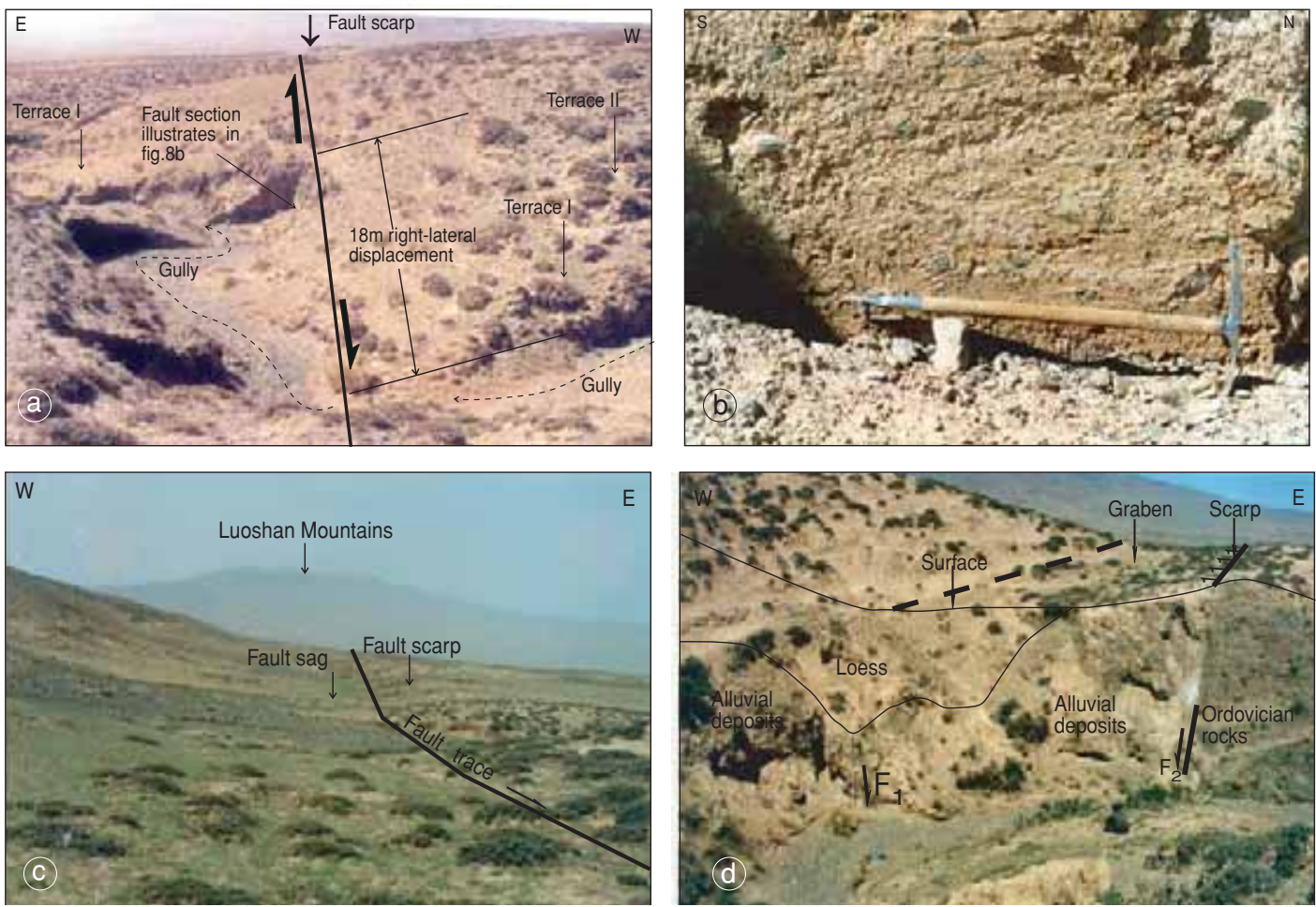

Fig. 7a-d. Evidence of activity of the Luoshan Fault. a) A gully was dextrally offset by $18 \pm 1 \mathrm{~m}$ in Shiyaodong. Thick line indicates the trace of the fault; the large thick arrows show the movement direction of the fault. Dashed lines with arrows indicate the gully. Two terraces developed on the upthrown block and one terrace on the downthrown block. The topographic map of the gully is illustrated in fig. 10. b) Fault exposure with nearly horizontal striae near Shiyaodong. c) Fault sag in Wangdengjuan. Thick line with arrow indicate fault. d) Cross section of a graben in Wangdengjuan. The dashed line indicates buried fault. Thick lines indicates faults. 

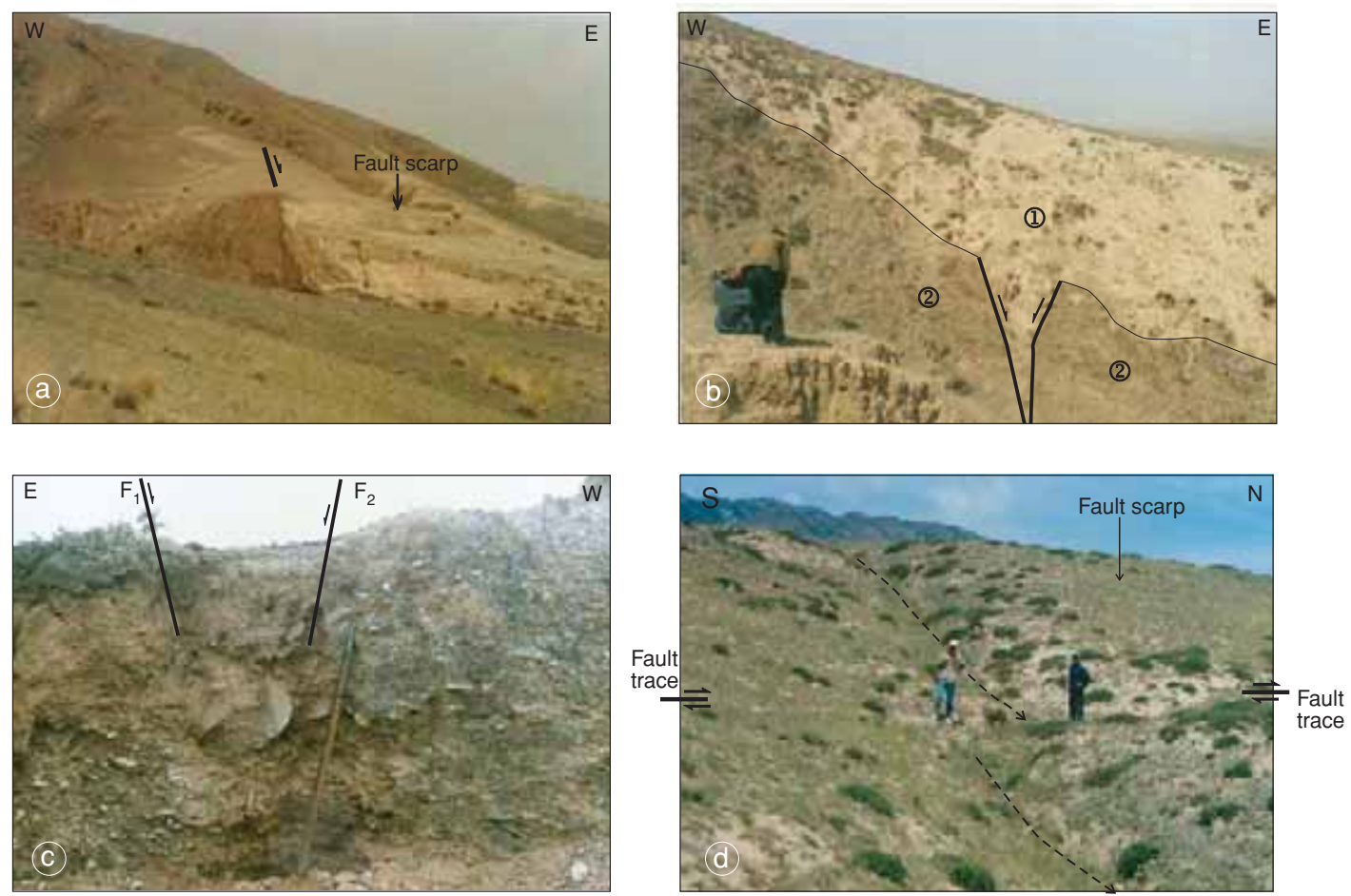

Fig. 8a-d. Surface rupture features; some of them may be related to the most recent slip on the fault. a) View of a fault section and scarp with free face at Zhangjiashanpo. b) Normal fault section near Zhangjiashanpo. Thick lines with arrows indicate normal faults. 1 - Quaternary loess; 2 - Ordovician rocks. c) Small graben feature in Shiyaodong segment. Thick lines with arrows indicate normal faults. The graben is formed in a younger alluvial fan. The deposits between faults $F_{1}$ and $F_{2}$ consist of gravel mixed with redeposited loess, and alluvial gravel bed exposures on the other portion. d) Small gully dextrally offset by $3.6 \mathrm{~m}$ during the last rupture event at Shiyaodong.

The Zhangjiashanpo section $\mathrm{SF}_{6}$ (fig. 2): strikes $340^{\circ}$, being $20 \mathrm{~km}$ long. The fault signs the boundary between the Quaternary deposits and Ordovician rocks, and is enhanced by an east-dipping normal fault. Many remarkable fault scarps comprising fresh free-faces are observed (fig. 8a). Because free-faces will be eroded away within hundreds of years (Wallace, 1977), the latest rupture event possibly occurred within one thousand years. Several meters west of the fault scarps, another normal fault section outcrops in many gully walls (fig. 8b), however, there are no traces on the surface along this fault splay. This suggests that the fault ruptured the surface many times. South of Miaoshan, the fault disappeared in the loess plateau.
Because of left-stepping of secondary shear faults along the right-lateral strike slip fault zone, pressure structures occur (Deng and Zhang, 1984; Chen and Deng, 1985). The thrust fault $\mathrm{SF}_{2}$ formed between $\mathrm{SF}_{1}$ and $\mathrm{SF}_{3}$, and pressure ridges formed between the other overlapping segments (fig. 6).

\section{Historical earthquakes rupture zone in the Luoshan Fault}

As mentioned before, a historical earthquake $\boldsymbol{M} \approx 7.3$ occurred in the area close to Luoshan Fault in 1561(Gu et al., 1989). Although we know nothing about the earthquake fault, the 
Table I. TL sample data (dated by TL laboratory of Institute of Geology, China Seismological Bureau, Beijing).

\begin{tabular}{ccccccc}
\hline $\begin{array}{c}\text { Sample } \\
\text { number }\end{array}$ & Location & $\begin{array}{c}\text { Depositional } \\
\text { environment }\end{array}$ & $\begin{array}{c}\text { Temperature } \\
\text { range }\left({ }^{\circ} \mathrm{C}\right)\end{array}$ & $\begin{array}{c}\text { Equivalent } \\
\text { dose }(\text { Grays })\end{array}$ & $\begin{array}{c}\text { Dose rate } \\
(\mathrm{Grays} / \mathrm{ka})\end{array}$ & TL age (yr) \\
\hline ST & Terrace II in SYD & Fine alluvial sand & $310-350$ & $44.80 \pm 3.18$ & $4.57 \pm 0.36$ & $9800 \pm 750$ \\
MA & Alluvial fan in MCG & Fine alluvial sand & $310-350$ & $319.24 \pm 24.58$ & $4.62 \pm 0.37$ & $69000 \pm 5400$ \\
sd1 & SYD trench & Eolian loess & $310-350$ & $19.74 \pm 1.18$ & $3.97 \pm 0.31$ & $4970 \pm 390$ \\
sd2 & SYD trench & Eolian loess & $310-350$ & $14.56 \pm 1.08$ & $4.65 \pm 0.36$ & $3130 \pm 240$ \\
sd3 & SYD trench & Eolian loess & $310-350$ & $10.08 \pm 0.87$ & $4.52 \pm 0.35$ & $2230 \pm 170$ \\
sm3 & SM trench & Fine alluvial sand & $310-350$ & $31.81 \pm 2.14$ & $3.95 \pm 0.34$ & $8200 \pm 600$ \\
\hline
\end{tabular}

SYD-Shiyaodong, MCG-Machanggou, SM-Shuangmiao.

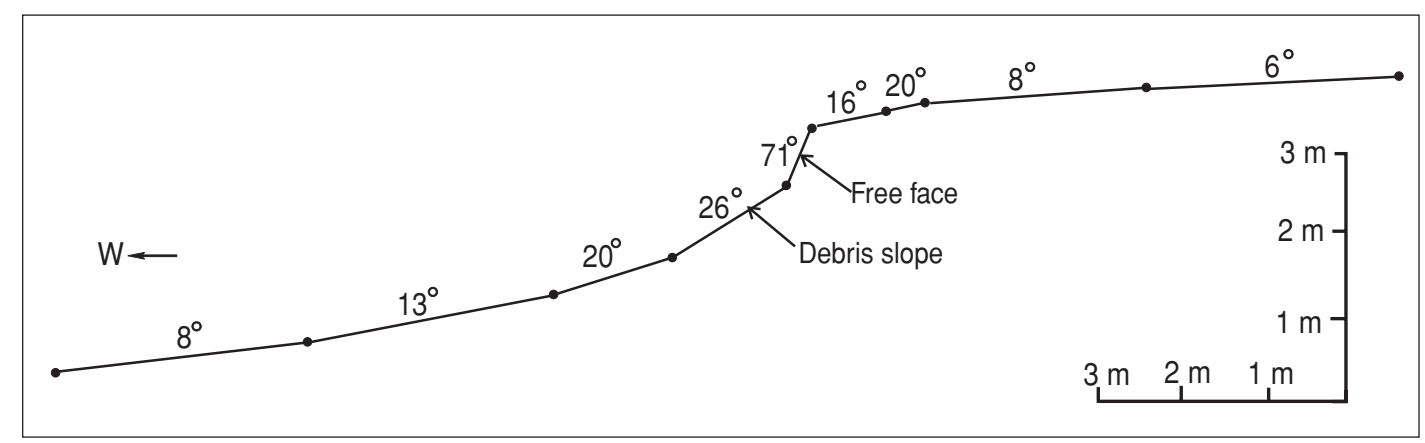

Fig. 9. Topographic profile across Zhangjiashanpo fault scarp surveyed by total station.

surface ruptures found along the Luoshan Fault could indicate that the Luoshan Fault is responsible for the 1561 earthquake.

The fault traces always offset the Quaternary deposits, and frequently offset Holocene deposits and geomorphic units, with the last rupture buried by recent alluvial material (figs. 3, 4, 5 and $8 \mathrm{c}$ ). Moreover, the displacement of « $\mathrm{V} »$ shape small gullies, only tens of meters long and one meter deep, could suggest that they were formed recently. The headwater erosion velocity is estimated to be $8.46 \mathrm{~cm} / \mathrm{yr}$ in this region (Cheng et al., 1984), while these gullies should reasonably be formed within one thousand years. Sixteen of these gullies (Order IV in table I) show dextral offsets of 1.5 m-5.4 m (fig. 8d), and could account for the most recent event which occurred along the Luoshan Fault.

Finally, further evidence for recent slip of the fault can be decided by the study of the free-face
(Wallace, 1977). For example, a free-face in loess deposits in ZhangJiashanpo is $0.7 \mathrm{~m}$ high with $71^{\circ}$ (fig. 9). Here the original upper slope is $6^{\circ}$, a transition portion with $16^{\circ}-20^{\circ}$ formed between free-face and original upper slope, and a $26^{\circ}$ debris slope developed near free-face. The dip of the fault is $55^{\circ}$ that can be seen in the north wall of a gully (fig. 8a). Thus, the slope angle of the free-face is larger than that of the fault, indicating that the fault scarp is still under the evolution of gravity, thus very young.

\section{Horizontal slip rate}

Horizontal offsets of streams are the most ubiquitous and prominent phenomena along the Luoshan Fault (fig. 6), and they can be used both to evaluate the kinematics of the fault and to calculate the horizontal slip rate. 
We studied the right-lateral strike-slip rate of the Luoshan Fault in the Shiyaodong and Machanggou sites (fig. 6, two inset boxes).

\subsection{Shiyaodong site (fig. 6)}

Here, streams and gullies are dextrally displaced by different amounts. The topographic map of a $18 \mathrm{~m} \pm 1 \mathrm{~m}$-displacement gully was measured by total station (fig. 10), and this gully is illustrated in fig. 8a. Two depositional terraces were formed in the upthrown block and one depositional terrace, being eroded away close to the fault, was formed in the downthrown block. Terrace I is about $1-1.5 \mathrm{~m}$ high and the top of the terrace is composed of $0.5 \mathrm{~m}$ gray black soil. The other parts of terrace I were composed of gravel and sand layers. Terrace II is 5-6 m high. Its top and bottom are composed of light yellowish sand with a height of $2 \mathrm{~m}$ and lower than

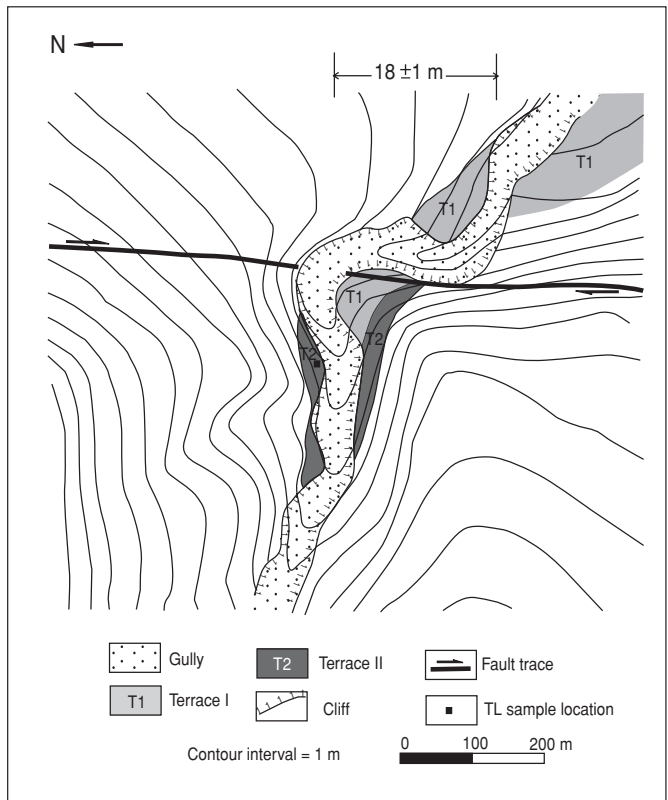

Fig. 10. Topographic map of fault landform near Shiyaodong surveyed by total station (Shiyaodong site in fig. 6). The gully has been right-laterally offset $18 \pm 1 \mathrm{~m}$ and illustrated in fig. $7 \mathrm{a}$.
$1 \mathrm{~m}$, respectively. The middle part of terrace II is composed of gravel. The $18 \pm 1 \mathrm{~m}$-offset is the displacement of the central line of the gully between the two sides of the fault. The incision age postdates the deposition age, so the age of the oldest depositional terrace represents the maximum age of the displacement. A rough indication of the terrace age is indicated by a TL (numbering ST) dating of $9800 \pm 750$ years BP (table I) collected below the top surface of the terrace II. Therefore, the minimum right-lateral strike-slip rate could have been about $1.8 \pm 0.2$ $\mathrm{mm} / \mathrm{yr}$ during the Holocene.

\subsection{Machanggou Site (fig. 6)}

Machanggou alluvial fan is the oldest in the eastern piedmont of the Luoshan Mountain, and it is clearly cut and dextrally displaced by the fault. Determining the offset of the fan is difficult, because we cannot find suitable indications to measure it. As soon as an alluvial fan forms, streams and gullies will carve on it, the largest streams may be regarded as coeval with the alluvial fan, and the displacement of the largest stream could approximate the displacement of the fan.

The Machanggou gully is the largest gully that incised into the highest and oldest Machanggou alluvial fan, and the displacement of the southern gully wall between the two points $\mathrm{A}$ and $\mathrm{B}$ is $171 \pm 10 \mathrm{~m}$ measured by total station, it is the largest offset value along the Luoshan Fault. From the south wall of the Machanggou gully, a sample (numbering MA) of alluvial fine sand was collected $3 \mathrm{~m}$ below the surface of the oldest alluvial fan (black triangle, fig. 6), its TL dating being $69000 \pm 5400$ years BP (table I). According to the displacement of the alluvial fan, the right-lateral strike-slip rate is $2.5 \pm 0.3 \mathrm{~mm} / \mathrm{yr}$ since Late Pleistocene. The formation age of the alluvial is older than the formation age of the gully, so the $2.5 \pm 0.3$ $\mathrm{mm} / \mathrm{yr}$ slip-rate should be a minimum value. It is worth noting that the longer the streams and gullies developed, the larger they have been displaced by the fault motions. By grouping these streams and gullies according to their scales, it is possible to use the average displacement of 
Table II. Statistics of horizontal displacements of gullies along the Luoshan Fault.

\begin{tabular}{|c|c|c|c|}
\hline $\begin{array}{l}\text { Order of } \\
\text { gullies }\end{array}$ & $\begin{array}{l}\text { Displacement values } \\
(\mathrm{m})\end{array}$ & $\begin{array}{l}\text { The range of } \\
\text { displacement values }\end{array}$ & $\begin{array}{c}\text { Averaging } \\
\text { value }\end{array}$ \\
\hline I & $59,52,60,50,60$ & $50-60$ & 80 \\
\hline II & $\begin{array}{l}16,22,26,18,15,23,19,21 \\
22,18,18,18,20,31,25,28.3 \\
\quad 15.3,24,25,28,23,22\end{array}$ & $15-31$ & 21.7 \\
\hline III & $\begin{array}{c}8,7.5,8.5,11,8,9,10,12.5,12,14,8.4 \\
8,10,13,12,7,14,10,14,15,10,9,10 \\
7,15,8.3,8.3,9,7,7.5,7,13,7,7,9,8 \\
12,15,10,13,8,10.7,8\end{array}$ & $7-15$ & 10.02 \\
\hline IV & $\begin{array}{c}4,4.7,2,1.5,4,2.7,3.6,5.4 \\
3,3,5.4,4,5,3,5,5\end{array}$ & $1.5-5.4$ & 3.8 \\
\hline
\end{tabular}

each group to compute an average slip rate. According to our observation, the gullies along the Luoshan Fault can be divided into four groups characterized by similar width-length and terrace orders.

In group I, the gullies eroded upstream the Ordovician rocks but did not erode upstream to the watershed, and three alluvial terraces are developed along the gullies.

The gullies of group II are located only within the alluvial fan surface, and did not erode upstream to the Ordovician units, and two terraces developed.

The gullies of group III are tens-of-meterslong and 1-2 m deep, and are also craved only in the alluvial fan.

Finally, the gullies of group IV only several meters long and less than $1 \mathrm{~m}$ deep are the smallest gullies along the Luoshan Fault.

87 offset values were measured along the fault (table II) and arranged into related groups. Most measurements are made with a tape measure and some of them with total station. Considering that the average displacement of order II is $21.7 \pm 1 \mathrm{~m}$, and that the age of group II in Shiyaodong is $9800 \pm$ \pm 750 years $\mathrm{BP}$, the rough average slip rate related to this period is $2.2 \pm 0.2 \mathrm{~mm} / \mathrm{yr}$.

Altogether, the minimum slip-rate, considering the three values above, is $2.15 \pm 0.2 \mathrm{~mm} / \mathrm{yr}$ (mean value of $1.8 \pm 0.2 \mathrm{~mm} / \mathrm{yr}$ and $2.5 \pm 0.3$ $\mathrm{mm} / \mathrm{yr})$.

\section{Paleoseismic analyses}

Although six trenches were excavated along the Luoshan Fault (fig. 2), evidence for individual paleoearthquake can only be found in the Shiayaodong and Shuangmiao trenches. The other trenches were excavated on the youngest surfaces, and where exposing only the most recent faulting event, one $\log$ of these trenches was shown in fig. 5 .

\subsection{Shiyaodong trench}

This trench was excavated across the $\mathrm{SF}_{4}$, and particularly across a straight $2.2 \mathrm{~m}$ high fault scarp cutting the alluvial fan near the farm of Shiyaodong. The stratigraphical succession observed in the south wall of the trench is composed mainly of eolian silt (loess) and alluvial gravel (fig. 11a,b).

Two faults $F_{1}$ and $F_{2}$ were exposed on the wall. The sediments west of the $F_{2}$ are composed of alluvial gravel with horizontal beddings. The sediments between $F_{1}$ and $F_{2}$ are also composed of alluvial gravels, but layers have been titled eastward by the movement of faults. The deposits related to the faulting events are found on the eastern side of $F_{1}$. The faulting history could be tentatively suggested by the presence of lenses of gravels in the hangingwall that could be interpret- 
(a)

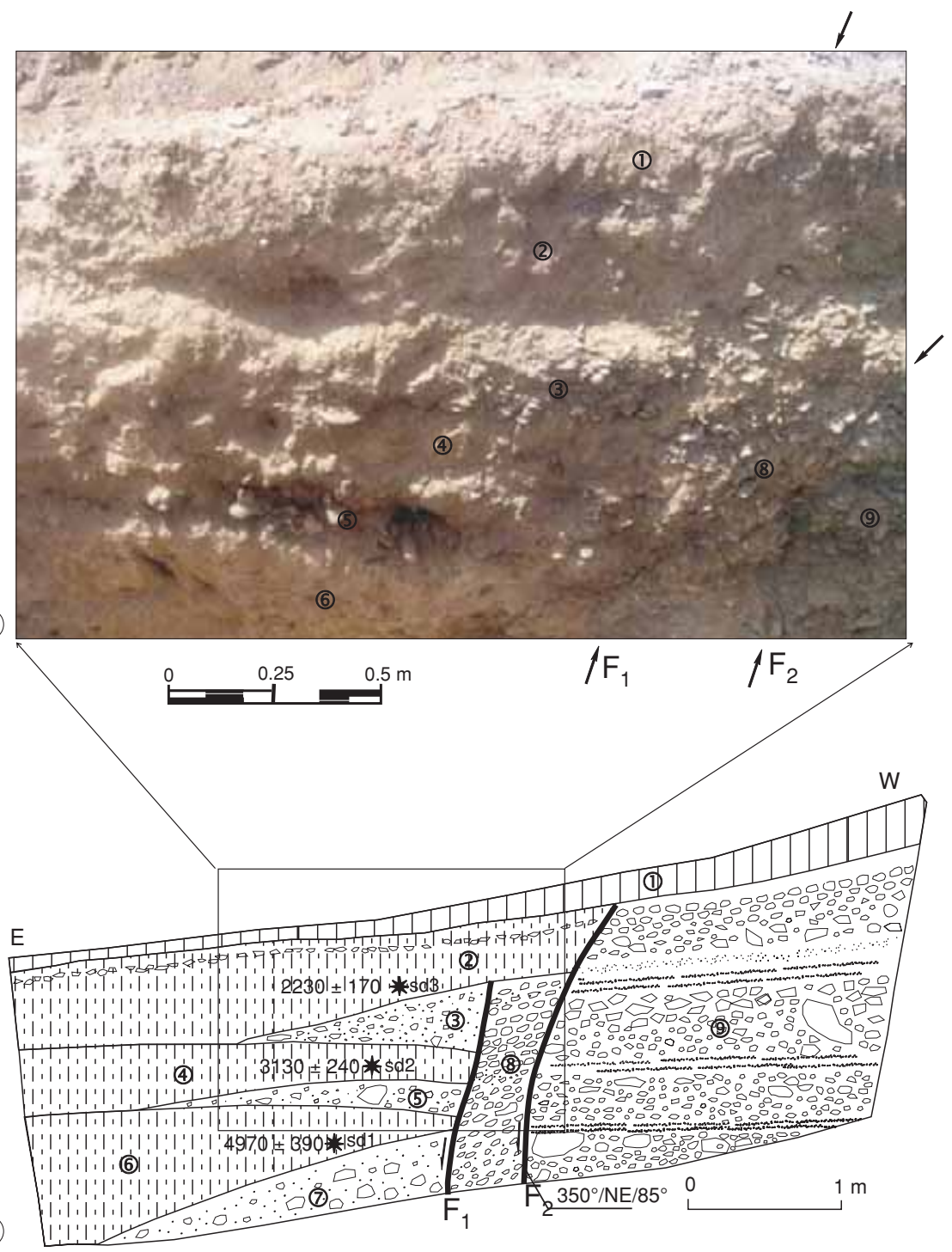

Fig. 11a,b. South wall of Shiyaodong trench. a) Photo of the south wall. Arrows indicate faults. b) Log of the south wall. The numbers represent stratigraphic units: 1 - recent alluvial loess mixed with small gravel; 2 - redeposited loess, whereas a layer of gravel exists in the upper part of the bed; 3 - colluvial wedge consisting of gravel and redeposited loess. The thickness of this unit is about $0.4 \mathrm{~m}$ near the fault and extends $1.5 \mathrm{~m}$ away from the fault; 4 - redeposited loess, and they are brought by sheet flow on the upthrown block of the fault and eolian deflation; 5 - colluvial wedge which consists of gravel mixed with redeposited loess. This unit has a thickness of $0.2 \mathrm{~m}$ in the vicinity of the fault and thins away from the fault. It extends $2 \mathrm{~m}$ and then lenses out; 6 - redeposited loess; 7 - colluvial wedge (not well exposed) composed of coarse gravel and loess; 8 - fracture zone of about $0.5 \mathrm{~m}$ width consisting of gravel from alluvial fan, in which the beddings of gravel dip eastwards; 9 - gravel bed of alluvial fan, consisting of coarse gravel bedded with sand. The large box shows the area of photo. Stars represent TL sample locations. Sample names and ages are also labeled on the log. 
(a)

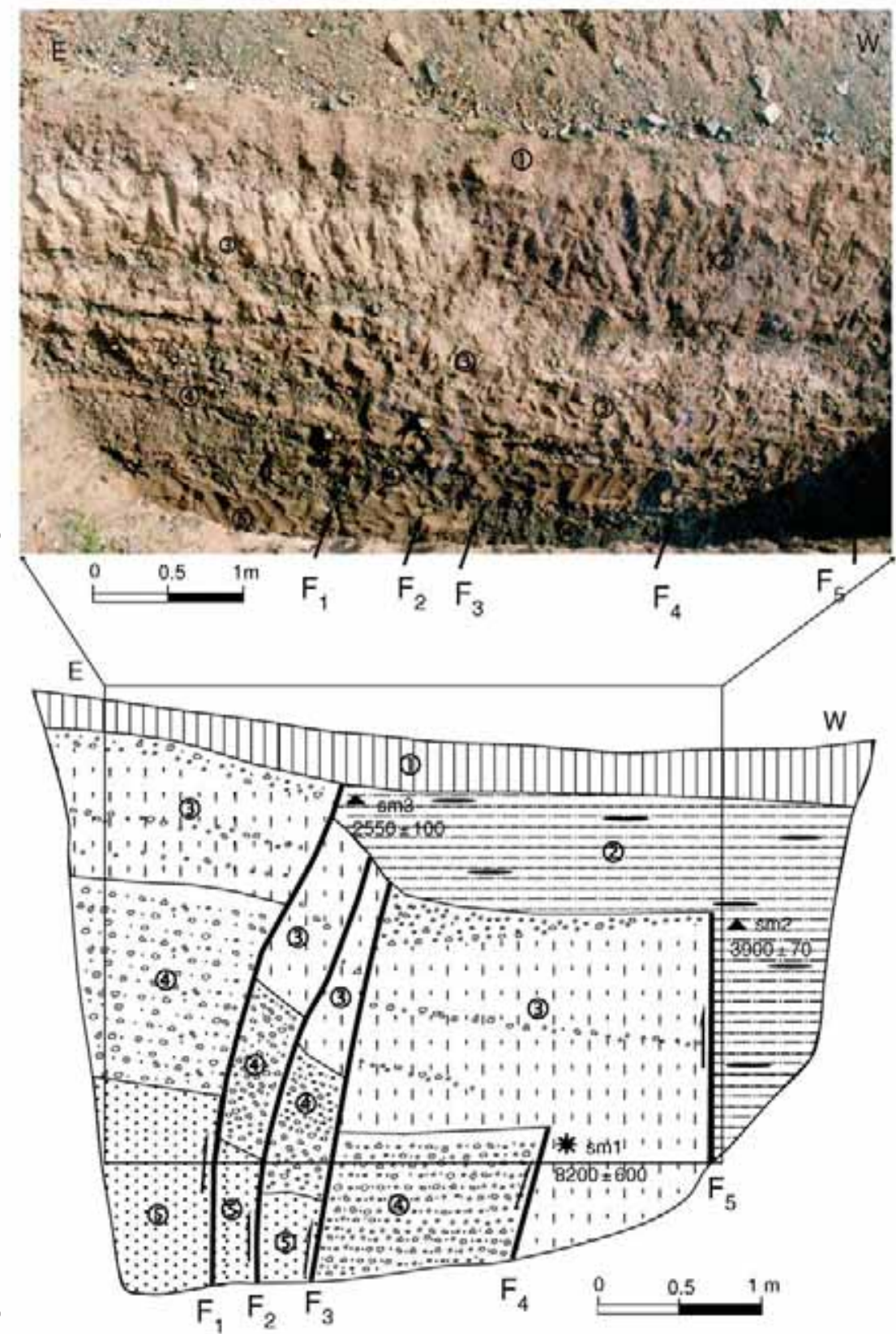

Fig. 12a,b. South wall of Shuangmiao trench. a) Photo of the south wall. Arrows indicate faults. b) Log of the south wall. The numbers represent stratigraphic units: 1 - recent hillslope deposits; 2 - light black soil containing a little peat; the materials of this unit came from hillslope and deposited in the fault sag; 3 - redeposited loess interbedded with three layers of gravel; 4 - gravel interbeded with sand; 5 - fine alluvial sand. The big box shows the area of the photo. Stars represent TL sample locations. Sample names and ages are also labeled on the log. 
ed as colluvial wedges that formed during the degradation of unit 9 after each surface faulting. The colluvial wedges consist primarily of coarse cobbles mixed with fine silts without beddings. It is thought that the right lateral strike slip Luoshan Fault is characterized by pivotal movement, a minor normal element was accompanied by right lateral strike slip along the Shiyaodong segment, the fault scarps have shown that normal faulting existed all the time, hence, colluvial wedges are small along the Luoshan Fault. Two paleoearthquakes are determined from this trench. Units 3 and 5 can be interpreted as two colluvial wedges and each of them probably represents one paleoevent. Unit 7 is perhaps another colluvial wedge, but is not well exposed.

The most recent event occurred along fault $\mathrm{F}_{2}$ which cut layer 3 and is covered by layer 1 , there was no colluvial wedge related to this paleoearthquake probably because of the geometry of $\mathrm{F}_{1}$ (fig. 11a,b). Three TL age samples of sd1, sd2 and $\mathrm{sd} 3$ were collected from the bottom of debris slope over every possible colluvial wedge (fig. 11a,b). Their ages are $4970 \pm 390$ years BP, $3130 \pm 240$ years BP and $2230 \pm 170$ years BP (table I), so the two paleoearthquakes (DE1 and DE2) occurred before $3130 \pm 240$ years BP but after $4970 \pm 390$ years $\mathrm{BP}$, before $2230 \pm 170$ years BP and after $3130 \pm 240$ years BP. The most recent event occurred after $2230 \pm 170$ years BP and was responsible for the 1561 A.D. earthquake.

\subsection{Shuangmiao trench}

This trench is excavated across a west-facing scarp. Here, the fault is shown by a $2 \mathrm{~m}$ high reverse fault scarp formed on the alluvial fan (fig. $7 \mathrm{c})$. The sediments observed in the south wall of the trench are mainly alluvial gravels, sand and soil (fig. 12a,b).

Five high-angle reverse faults can be recognized. The sediments eastward of $F_{1}$ are alluvial gravels, which could be reasonably tilted by the thrusting motion. The growing of the east-dipping-reverse-fault trapped the deposits at the foothill. Firstly, the right lateral strike slip is dominant and the thrusting motion is minor, secondly, the hillslope deposits (unit 2) accumulated quickly along the fault scarp, so the colluvial fabric was undeveloped. At least three paleoearthquakes can be recognized at this site. The first paleoevent occurred during the deposition of unit $3 . \mathrm{F}_{4}$ cuts unit 4 and the lower part of unit 3 , and then was buried by the upper part of this unit. The second paleoevent occurred during the deposition of unit 2 as showed by faults $F_{2}, F_{3}$ and $F_{5}$. These faults cut units 3, 4 and 5, particularly, $\mathrm{F}_{5}$ cut the lower part of unit 2, and were buried by the upper part of unit 2 . The last paleoevent occurred along fault $F_{1}$, it cut unit 2 and was buried by unit 1 .

In order to determine the timing of these paleoevents, three samples were collected and dated. These are: sample sm1 composed of fine sand with TL age of $8200 \pm 600$ years BP (table I); sample sm2 consisted of peat deposits and its ${ }^{14} \mathrm{C}$ age is $3900 \pm 70$ years $\mathrm{BP}$, dendrochronologically corrected age is $4150 \pm 120$ C.BP; sample sm3 was taken from the peat deposits of unit 2 , its ${ }^{14} \mathrm{C}$ age is $2550 \pm 100$ years $\mathrm{BP}$, dendrochronologically corrected age is $2550 \pm 190$ C.BP ${ }^{14} \mathrm{C}$ samples were dated by ${ }^{14} \mathrm{C}$ laboratory of Institute of Geology, China Seismological Bureau. According to these datings, the first paleoevent (GE1) occurred after $8200 \pm 600$ years BP; the second paleoevent (GE2) occurred after $4150 \pm 120$ years C.BP; the third paleoevent (GE3) occurred after $2550 \pm 190$ years C.BP and should correspond to 1561 A.D. earthquake.

\section{Sequence of faulting events and recurrence intervals}

Figure 13 summarizes the paleoseismic events identified in the two trenches. Four paleoevents can be determined since Holocene along the Luoshan Fault. The oldest paleoevent $\left(E_{1}\right)$ is recognized only in Shuangmiao trench, and it occurred after $8200 \pm 600$ years BP. The second paleoevent $\left(\mathrm{E}_{2}\right)$ was recognized both in Shiyaodong and Shuangmiao trenches; it occurred between $3130 \pm 240$ years BP and $4150 \pm 120$ years C.BP. The third $\left(\mathrm{E}_{3}\right)$ paleoevent can only be recognized in Shiyaodong trench, where it occurred before $2230 \pm 170$ years BP. The most recent event was recognized in both trenches, and it occurred after $2230 \pm 170$ years BP in Shiyaodong trench and after $2550 \pm 190$ years BP in Shuangmiao 


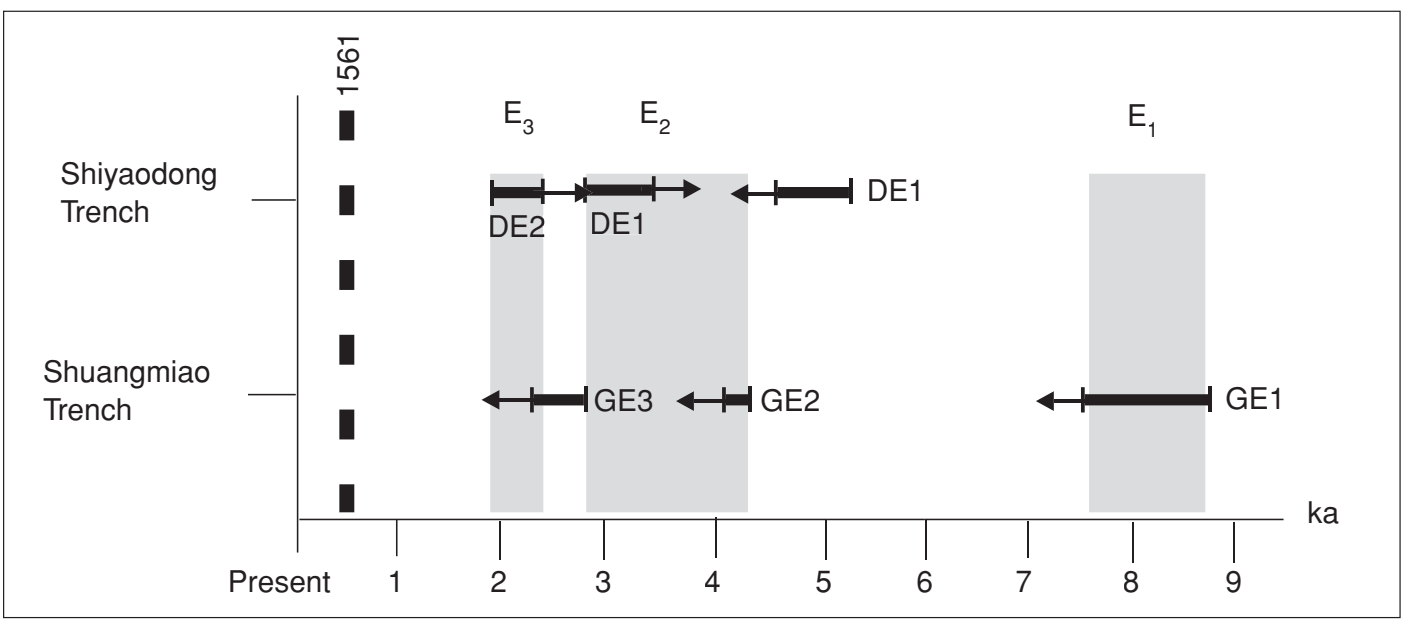

Fig. 13. Comparison of paleoearthquakes and recurrence interval for large earthquakes documented in trenches along Luoshan Fault. Thick bars show the age range of TL from samples. Arrows indicate whether the earthquake occurred prior to or after that period. Dashed dark line indicates probable historical earthquake in 1561 A.D. $E_{1}-E_{3}$ indicate paleoevents and sequence, the time estimate corresponds to the shaded area.

trench. Combining with historical data, the last event could be the earthquake of 1561 A.D.

\section{Conclusions}

On the basis of field and aerial photo mapping and paleoseismological trenching, we have achieved the following results:

1) The Luoshan Fault is composed of six sections, and trending $350^{\circ}$ with a total length of 60 $\mathrm{km}$. The fault striae, and the right-lateral displacement of gullies and streams indicate that, unlike other faults in the northeastern margin of Tibetan plateau, the Luoshan Fault is a right-lateral strikeslip fault. According to the displacement of terraces and alluvial fans and their dating ages, the minimum right-lateral strike-slip rate was determined to be $2.15 \pm 0.2 \mathrm{~mm} /$ years since Late Pleistocene.

2) $\mathrm{A} \boldsymbol{M} \approx 7.3$ earthquake occurred in 1561 A.D. in the area close to Luoshan Mountain. Through detailed fieldwork in this area, we related the Luoshan Fault to this earthquake. The whole fault-rupture is about $60 \mathrm{~km}$, while the largest horizontal displacement evaluated for this earthquake is $5.4 \mathrm{~m}$, the average being $3.8 \mathrm{~m}$.
3) By means of paleoseismological analyses carried out within 2 trenches, besides the 1561 earthquake, we find evidence for three paleoearthquakes along the Luoshan Fault, and they occurred after $8200 \pm 600$ years BP, between $3130 \pm$ \pm 240 years BP and $4150 \pm 120$ years C.BP, and before $2230 \pm 170$ years BP, respectively.

\section{Acknowledgements}

This research was supported by China 973 Project (G1998040701) and China seismic science fund (102086-95087421). The authors thank their colleagues Yang Pin and Wang Ping for their help. We are grateful to Dr. Paolo Galli for carefully review of the manuscript that greatly improved this paper.

\section{REFERENCES}

AvouAC, J.P. and P. TAPPONNIER (1993): Kinematic model of active deformation in Central Asia, Geophys. Res. Lett., 20 (10), 895-898.

Burchfiel, B.C., P. Zhang, Y. Wang, W. Zhang, D. JiaO, F. Song, Q. Deng, P. Molnar and L. Royden (1991): 
Geology of the Haiyuan Fault zone, Ningxia Hui Autonomous Region, China and its relation to the evolution of the northeastern margin of the Tibetan plateau, Tectonics, 10 (6), 1091-1110.

Chai, C., Y. Liao, W. Zhang and W. Xu (2001): Late Quaternary paleoearthquakes and their rupture features along the Lingwu Fault, Seismol. Geol., 23 (1), 15-23.

Cheng, S. and Q. Deng (1985): The Pull-Apart Basins within Nanxihuashan Fault Zone, Research on Crustal Movement (Seismological Press, Beijing, China), 1, 98-106 (in Chinese).

Cheng, S., G. Peng and H. Li (1984): Offset gullies and recurrence time of $\boldsymbol{M}=8.5$ strong earthquakes along the fault zone of northern piedmont of Nanhuashan, Haiyuan, Ningxia, Seismol. Geol., 6 (4), 25-38 (in Chinese).

Deng, Q. and Y. LiaO (1996): Paleoseismology along the range-front fault of Helan Mountains, North Central China, J. Geophys. Res., 101 (B3), 5873-5893.

DENG, Q. and P. ZHANG (1984): Research on the geometry of shear fracture zones, J. Geophys. Res., 89 (B7), 5699-5710.

Deng, Q. and P. Zhang (1990): Haiyuan Active Fault (Institute of Geology, State Seismological Bureau, Seismological Bureau of Ningxia Hui Automous Province, Seismological Press, Beijing, China), pp. 286 (in Chinese).

Deng, Q., S. Chen, F. Song, S. Zhu, Y. Wang, W. Zhang, D. JiAO, B.C. BuRCHFIEL, P. MOLNAR, L. ROYdEN and P. ZHANG (1986): Variations in the geometry and amount of slip on the Haiyuan Fault Zone, China and the surface rupture of the 1920 Haiyuan earthquake, in Earthquake Source Mechanics, Geophysical Monograph 37 (Maurice Ewing 6), 169-182.

Gu, G., T. LI and Z. SHI (1989): Catalogue of Chinese Earthquakes (1831 B.C.-1969 A.D.) (Science Press, Beijing, China), 50-226.

Liao Y., C. Chai, W. Zhang and W. Xu (2000): The active features and slip rate of Lingwu faults in Late Quaternary, Earthquake Research in China, 6 (2), 158-165 (in Chinese).

Molnar, P. and P. TAPPONnIER (1975): Cenozoic tectonics of Asia: effects of a continental collision, Science, 189 (8), 419-426.

MolnAR, P. and P. TAPPONNIER (1978): Active tectonics of Tibet, J. Geophys. Res., 85, 5361-5375.
Qidong, D., S. Fengmin, Z. Shilong, M. I-i, W. Zhang, B.C. Burchfiel, P. Molnar and P. Zhang (1984): Active faulting and tectonics of the Ningxia Hui Autonomous Region, China, J. Geophys. Res., 89, 4427-4445.

Research Group on Active Fault System AROUnd ORdos Massif (1988): Active Fault System Around Ordos Massif (State Seismological Bureau, Seismological Press, Beijing, China) (in Chinese), 143-148.

Research Group on Altyn Active Fault (1992): Altyn Active Fault Zone (State Seismological Bureau, Seismological Press, Beijing, China) (in Chinese), 150-156.

TAPPONNIER, P. and P. MOLNAR (1977): Active faulting and tectonics in China, J. Geophys. Res., 82, 2905-2930.

WANG, Y., F. Song, Z. LI, H. You and P. AN (1990): Study on recurrence intervals of great earthquakes in the Late Quaternary of Xiangshan-Tianjingshan faults in Ningxia, Earthquake Research in China, 6 (2), 15-24 (in Chinese).

Wallace, R.E. (1977): Profiles and ages of young fault scarps, North-Central Nevada, Geol. Soc. Am. Bull., 88, $1276-1280$.

Xu, X., W. Chen, W. Ma, G. Yu and G. Chen (2002): Surface rupture of the Kunlunshan earthquake $\left(M_{\mathrm{s}} 8.1\right)$, Northern Tibetan plateau, China, Seismol. Res. Lett., 73 (6), 884-892.

Zhang, B., Y LiaO, S. GuO, R.E. WaLlace, R.C. BuCKNAM and T.C. HANKS (1986): Fault scarps related to 1739 earthquake and seismicity of the Yinchuan graben, Ningxia Huizu Zizhiqu, China, Bull. Seismol. Soc. Am., 76,1253-1287.

Zhang, P., P. Molnar, B.C. Burchfiel, L. Royden, W. Zhang, D. Jiao, Q. Deng, Y. Wang and F. Song (1988): Bounds on the Holocene slip rate along the Haiyuan Fault, North Central China, Quat. Res., 30, 151-164.

Zhang, P. B. C. Burcheiel, P. Molnar, W. Zhang, D. JiaO, Q. Deng, Y. Wang, L. Royden and F. Song (1990): Late Cenozoic tectonic evolution of the Ningxia-Hui Autonomous Region, China, Geol. Soc. Am. Bull., 102, 1484-1498.

Zhang, P., B.C. Burchfiel, P. Molnar, W. Zhang, D. JiaO, Q. Deng, Y. WAng, L. Royden and F. Song (1991): Amount and style of Late Cenozoic deformation in the Liupan shan area, Ningxia Autonomous Region, China, Tectonics, 10 (6), 1111-1129. 
